\title{
In vivo analgesic, antipyretic, and anti-inflammatory potential in Swiss albino mice and in vitro thrombolytic activity of hydroalcoholic extract from Litsea glutinosa leaves
}

Rumpa Bhowmick ${ }^{1}$, Md Shahid Sarwar ${ }^{2}$, Syed Masudur Rahman Dewan ${ }^{1}$, Abhijit Das $^{1}$, Binayok Das ${ }^{3}$, Mir Muhammad Nasir Uddin ${ }^{4}$, Md Siddiqul Islam ${ }^{5}$ and Mohammad Safiqul Islam ${ }^{1^{*}}$

\begin{abstract}
Background: The study was conducted to evaluate the in vitro thrombolytic activity, and in vivo analgesic, anti-inflammatory and antipyretic potentials of different hydrocarbon soluble extracts of Litsea glutinosa leaves for the first time widely used in the folkloric treatments in Bangladesh. This work aimed to create new insights on the fundamental mechanisms of the plant extracts involved in these activities.

Results: In thrombolytic activity assay, a significant clot disruption was observed at dose of $1 \mathrm{mg} / \mathrm{mL}$ for each of the extracts (volume $100 \mu \mathrm{L}$ ) when compared to the standard drug streptokinase. The $\mathrm{n}$-hexane, ethyl acetate, chloroform, and crude methanolic extracts showed $32.23 \pm 0.26,37.67 \pm 1.31,43.13 \pm 0.85$, and $46.78 \pm 0.9 \%$ clot lysis, respectively, whereas the positive control streptokinase showed $93.35 \pm 0.35 \%$ disruption at the dose of 30,000 I.U. In hot plate method, the highest pain inhibitory activity was found at a dose of $500 \mathrm{mg} / \mathrm{kg}$ of crude extract $(15.54 \pm 0.37 \mathrm{sec})$ which differed significantly $(P<0.01$ and $P<0.001)$ with that of the standard drug ketorolac $(16.38 \pm 0.27 \mathrm{sec})$. In acetic acid induced writhing test, the crude methanolic extract showed significant $(P<0.01$ and $P<0.001)$ analgesic potential at doses 250 and $500 \mathrm{mg} / \mathrm{kg}$ body weight (45.98 and $56.32 \%$ inhibition, respectively), where ketorolac showed $64.36 \%$ inhibition. In anti-inflammatory activity test, the crude methanolic extract showed significant $(P<0.001)$ potential at doses 250 and $500 \mathrm{mg} / \mathrm{kg}$ body weight $(1.51 \pm 0.04$ and $1.47 \pm 0.03 \mathrm{~mm}$ paw edema, respectively), where ketorolac showed $1.64 \pm 0.05 \mathrm{~mm}$ edema after $3 \mathrm{~h}$ of carrageenan injection. In antipyretic activity assay, the crude extract showed notable reduction in body temperature $\left(32.78 \pm 0.46^{\circ} \mathrm{C}\right)$ at dose of $500 \mathrm{mg} / \mathrm{kg}$-body weight, when the standard (at dose $150 \mathrm{mg} / \mathrm{kg}$-body weight) exerted $33.32 \pm 0.67^{\circ} \mathrm{C}$ temperature after $3 \mathrm{~h}$ of administration.
\end{abstract}

Conclusions: Our results yield that the crude hydroalcoholic extract has better effects than the other in all trials. In the context, it can be said that the leaves of L. glutinosa possess remarkable pharmacological effects, and justify its traditional use as analgesic, antipyretic, anti-inflammatory, and thrombolytic agent.

Keywords: Acetic acid induced writhing, Analgesic, Anti-inflammatory, Antipyretic, Litsea glutinosa, Thrombolytic

\footnotetext{
* Correspondence: research_safiq@yahoo.com

'Department of Pharmacy, Noakhali Science and Technology University,

Sonapur, Noakhali 3814, Bangladesh

Full list of author information is available at the end of the article
} 


\section{Background}

Traditional knowledge regarding medicinal plants and their use by indigenous cultures is not only useful for maintenance of cultural traditions and biodiversity but also for community healthcare and drug development in the present and future. Therapies with synthetic tropical applications have many side effects and cannot be afforded by the people due to higher cost of the drug. For overcoming this problem plants growing around us are utilized without scientific validation. The use of higher plants and their extracts to treat infections is an age-old practice. Traditional medicinal practice has been known for centuries in many parts of the world. Herbal medicines are gaining interest because of their cost effective and eco-friendly attributes [1].

L. glutinosa belongs to the family Lauraceae and is a well-known evergreen species growing wild in the forest of Chittagong and Sylhet districts in Bangladesh. It is occasionally planted in most areas of the country [2]. Leaves are mucilaginous and considered for antispasmodic, emollient, and poultice. The leaves are also used in diarrhea and dysentery as well as for the treatment of wounds and bruises [2]. The leaves were reported for the treatment of the spontaneous and excessive flow of semen in young boys [3]. The leaf extract also shows antibacterial and cardiovascular activities [4]. The berries yield oil which is used by some tribal practitioners in the treatment of rheumatism. Tannin, $\beta$-sitosterol, and actinodaphnine are reported to be the common constituents of the species; and other constituents known are: Boldine, norboldine, laurotetanine, $\mathrm{n}$-methyllaurotetanine, n-methylactinodaphnine, quercetin, sebiferine, litseferine etc. [5].

Thrombosis is the fundamental pathophysiological process that underlies the acute coronary disorders such as pulmonary emboli, deep vein thrombosis, strokes and heart attacks; which are the main causes of morbidity and mortality in developed countries [6]. This disease is characterized by the development of a blood clot (thrombus) in the circulatory system of the body due to the failure of homeostasis which leads to vascular blockade and while recovering causes fatal consequences, such as myocardial or cerebral infarction, as well as death [7]. Therefore, anticoagulation therapy is the basis of management, and the proper choice of thrombolytic drugs [8].

Pain is an unpleasant sensory and emotional experience associated with actual or potential tissue damage [9]. By acting in the CNS or on the peripheral pain mechanism, analgesic compounds selectively relieves pain without significant alteration of consciousness. Actually analgesics are applied when the noxious stimulus cannot be removed or as adjuvant to more etiological approach to pain [10].

Inflammation is the response of living tissues to injury. It involves a complex array of enzyme activation, mediator release, and extravasations of fluid, cell migration, tissue breakdown and repair. Non-steroidal anti-inflammatory drugs (NSAID) are among the most commonly prescribed drugs due to their consistent effectiveness in the treatment of pain, fever, inflammation and rheumatic disorders. However, their use is associated with adverse effects at the level of digestive tract, ranging from dyspeptic symptoms, gastrointestinal erosions and peptic ulcers to more serious complications, such as over bleeding or perforation [11]. Therefore to overcome the toxicity of NSAID, the development of new anti-inflammatory drugs is still necessary and the natural product such as medicinal plants could lead in discovering new anti-inflammatory drugs with less undesirable effects [12].

Pyrexia or fever is usually caused as a secondary impact of infection, tissue damage, inflammation, graft rejection and malignancy or other diseased states. The body by its natural defense mechanism creates an environment where infectious agent or damaged tissue cannot survive. Generally, infected or damaged tissue initiates the enhanced formation of pro-inflammatory mediators (cytokines like interleukin $1 \beta, \alpha, \beta$ and TNF- $\alpha$ ) which increase the synthesis of prostaglandin $\mathrm{E}_{2}\left(\mathrm{PGE}_{2}\right)$ near preoptic hypothalamus area and thereby triggering the hypothalamus to elevate the body temperature [13]. Most of the antipyretic drugs normally prevent or inhibit COX-2 expression to reduce the elevated body temperature by inhibiting $\mathrm{PGE}_{2}$ biosynthesis. Moreover, these synthetic agents irreversibly inhibit COX-2 with high selectivity which is toxic to the hepatic cells, glomeruli, cortex of brain and heart muscles, whereas natural COX-2 inhibitors usually have lower selectivity with fewer side effects [14]. L. glutinosa was selected due to its availability in Bangladesh, therefore, used in rural areas for different treatments, and not such investigations have been carried out with this plant native to Bangladesh. Our main goal was to evaluate the in vivo antipyretic, anti-inflammatory and analgesic activity, and investigate the thrombolytic property of the plant leaves to validate its traditional uses.

\section{Results}

\section{Thrombolytic activity test}

The effective clot lysis percentage by four different extracts of the plant, positive thrombolytic control (Streptokinase) and negative control (water) is tabulated in Figure 1. From the Figure 1, it is evident that the percentage of clot lysis was $93.35 \pm 0.35 \%$ when $100 \mu \mathrm{l}$ of streptokinase (30,000 I.U.) was used as a positive control, while in case of negative control (water) the percentage of clot lysis was negligible $(7.06 \pm 0.95 \%)$. Among different extracts (concentration $1 \mathrm{mg} / \mathrm{ml}$ ), the crude methanolic extract showed highest activity (46.78 $\pm 0.90 \%)$, whereas n-hexane soluble fraction showed the lowest activity $(32.23 \pm 0.26 \%)$, which was much higher than the negative control (water). 


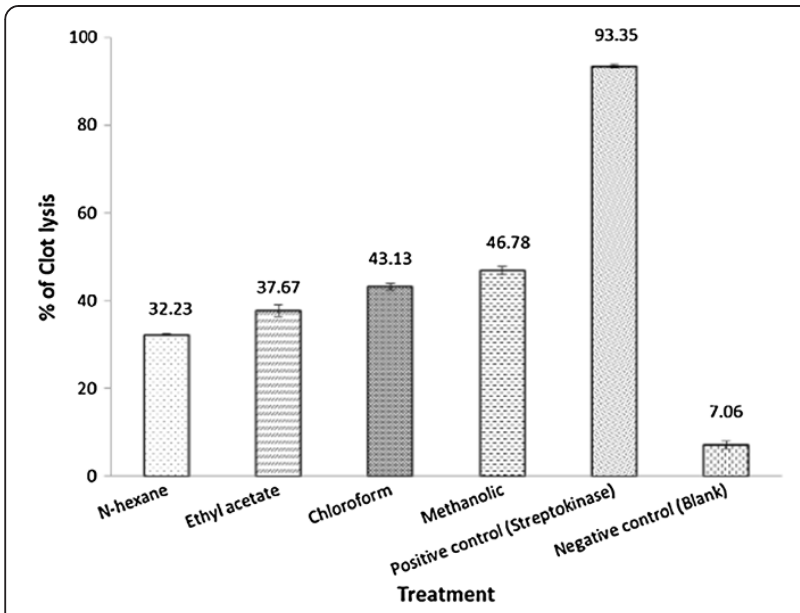

Figure 1 Thrombolytic effect of hydroalcoholic extracts of L. glutinosa leaves.

\section{Analgesic activity test Hot plate test}

Two doses of methanolic extract of leaves of L. glutinosa increased the animal (Swiss-albino mice) reaction time to the thermal stimulus which has been summarized in Table 1. The highest pain inhibition of thermal stimulus was found at a higher dose $500 \mathrm{mg} / \mathrm{kg}$ of crude extract which exhibited maximum time for the response against thermal stimuli $(15.54 \pm 0.37 \mathrm{sec})$ that is comparable to ketorolac $(16.38 \pm 0.27 \mathrm{sec})$ and found statistically significant $(\mathrm{P}<0.001$ and $\mathrm{P}<0.01)$ when compared to both the control and the standard drug.

\section{Acetic acid induced writhing test}

The effect of the methanolic extract of L. glutinosa leaves on acetic acid induced writhing in mice is given in Table 2. At the dose of $500 \mathrm{mg} / \mathrm{kg}$ of body weight, the crude extract produced $56.32 \%$ writhing inhibition in test animals.
The results were statistically significant $(\mathrm{P}<0.001)$ compared to the negative control.

\section{Anti-inflammatory activity test}

The anti-inflammatory effect of the crude methanolic extract using carrageenan induced oedema tests is expressed in Table 3. In this test, the positive control (ketorolac) significantly $(\mathrm{P}<0.05 ; \mathrm{P}<0.001)$ decreased the paw edema volume, $0.96 \pm 0.05$ to $1.64 \pm 0.05 \mathrm{~mm}$, at 1 to $3 \mathrm{~h}$ after carrageenan injection compared to control (saline) with edema volume. A maximum edema paw volume of $1.78 \pm 0.03 \mathrm{~mm}$ was observed in the control mice, after $3 \mathrm{~h}$ of the carrageenan injection. Mice administered with extract at $500 \mathrm{mg} / \mathrm{kg}$ body weight significantly decreased $(\mathrm{P}<0.05 ; \mathrm{P}<0.01)$ the carrageenan-induced edema paw volume from 1 to $3 \mathrm{~h}$ compared to the control (saline) at a dose of $2 \mathrm{ml} / \mathrm{kg}$ body weight. The highest reduction in the paw volume by the $500 \mathrm{mg} / \mathrm{kg}$ body weight was $1.47 \pm 0.03 \mathrm{~mm}$ when compared to that of the control (saline) $(1.78 \pm 0.03 \mathrm{~mm})$ at $3 \mathrm{~h}$.

\section{Antipyretic activity test}

Effect of different extracts of L. glutinosa on rectal temperature in mice is presented in Table 4. The subcutaneous injection of yeast suspension markedly elevated the rectal temperature after $18 \mathrm{~h}$ of administration. Treatment with the crude methanolic extract showed significant $(\mathrm{P}<0.05 ; \mathrm{P}<0.001)$ activity against induced pyrexia when compared with the control treatment.

\section{Discussion}

Thrombosis or blood clot formation is a critical event in which the damaged regions of the endothelial cell surface or blood vessel are blocked by the deposition of platelets, tissue factor and fibrin [15]. In the formation process the major role is played by platelets as the process of

Table 1 Effect of hydroalcholic extracts of $L$. glutinosa leaves on hot plate test

\begin{tabular}{|c|c|c|c|c|c|}
\hline \multirow[t]{2}{*}{ Treatment } & \multicolumn{5}{|c|}{ Response time (sec) } \\
\hline & $\mathrm{Oh}$ & $0.5 \mathrm{~h}$ & $1 \mathrm{~h}$ & $2 \mathrm{~h}$ & $3 \mathrm{~h}$ \\
\hline Control $(10 \mathrm{ml} / \mathrm{kg})$ & $8.30 \pm 0.63$ & $7.42 \pm 0.42$ & $7.50 \pm 0.39$ & $7.50 \pm 0.45$ & $7.18 \pm 0.33$ \\
\hline Standard (10 mg/kg) & $8.42 \pm 0.29$ & $11.59 \pm 0.32^{* *}$ & $13.58 \pm 0.38^{* *}$ & $14.98 \pm 0.48^{* * *}$ & $16.38 \pm 0.27^{* * *}$ \\
\hline n-hexane extract (250 mg/kg) & $8.27 \pm 0.32$ & $10.25 \pm 0.31^{* * c}$ & $10.94 \pm 0.13^{* * * a}$ & $11.27 \pm 0.58^{* * a}$ & $11.98 \pm 0.37^{* * * b}$ \\
\hline n-hexane extract (500 mg/kg) & $8.57 \pm 0.63$ & $11.01 \pm 0.66^{* *}$ & $11.43 \pm 0.25^{* * * b}$ & $11.59 \pm 0.76^{* * b}$ & $12.22 \pm 0.48^{* * * a}$ \\
\hline Ethyl acetate extract (250 mg/kg) & $8.73 \pm 0.30$ & $10.05 \pm 0.32^{* * a}$ & $10.30 \pm 0.74^{* * a}$ & $11.13 \pm 0.47^{* * b}$ & $11.39 \pm 0.65^{* * b}$ \\
\hline Ethyl acetate extract (500 mg/kg) & $8.70 \pm 0.56$ & $10.87 \pm 0.46$ & $11.36 \pm 0.27^{* * * b}$ & $11.48 \pm 0.59^{* * b}$ & $11.89 \pm 0.63^{* * b}$ \\
\hline chloroform extract (250 mg/kg) & $8.90 \pm 0.40$ & $10.58 \pm 0.29^{* * * c}$ & $11.03 \pm 0.40^{* * b}$ & $11.33 \pm 0.66^{* b}$ & $12.07 \pm 0.28^{* * * a}$ \\
\hline chloroform extract (500 mg/kg) & $8.87 \pm 0.15$ & $11.16 \pm 0.47^{* *}$ & $11.49 \pm 0.24^{* * * b}$ & $11.69 \pm 0.78^{* * b}$ & $12.31 \pm 0.54^{* * * b}$ \\
\hline Methanolic extract (250 mg/kg) & $9.10 \pm 0.33$ & $11.48 \pm 0.63^{* *}$ & $13.20 \pm 0.38^{* *}$ & $14.24 \pm 0.42^{* * *}$ & $15.06 \pm 0.36^{* * *}$ \\
\hline Methanolic extract (500 mg/kg) & $8.82 \pm 0.18$ & $11.54 \pm 0.52^{* *}$ & $13.38 \pm 0.44^{* *}$ & $14.56 \pm 0.49^{* * *}$ & $15.54 \pm 0.37^{* * * b}$ \\
\hline
\end{tabular}

Values are expressed as mean \pm SEM (Standard error mean); Values are calculated using one-way ANOVA followed by Dennett's test; ${ }^{* * *}$ indicates $P$ <0.001 and ${ }^{* *}$ indicates $\mathrm{P}<0.01$ when compared to control; ${ }^{a}$ indicates $\mathrm{P}<0.001{ }^{{ }^{b}}{ }^{\text {indicates }} \mathrm{P}<0.01$ and ${ }^{\mathrm{c}}$ indicates $\mathrm{P}<0.05$ when compared to standard drug; $\mathrm{p} .0 . ; \mathrm{n}=6$. 
Table 2 Effect of hydroalcholic extracts of $L$. glutinosa leaves on acetic acid induced writhing in mice

\begin{tabular}{ccc}
\hline Treatment & $\begin{array}{c}\text { Total writhing count } \\
\text { (Mean } \pm \text { SEM) }\end{array}$ & \% Inhibition \\
\hline Control & $17.4 \pm 2.50$ & - \\
Standard & $6.2 \pm 0.66^{* * *}$ & 64.36 \\
n-hexane extract $(250 \mathrm{mg} / \mathrm{kg})$ & $10.10 \pm 0.41^{* *}$ & 41.95 \\
n-hexane extract $(500 \mathrm{mg} / \mathrm{kg})$ & $8.7 \pm 0.57^{* * *}$ & 50.00 \\
Ethyl acetate extract $(250 \mathrm{mg} / \mathrm{kg})$ & $10.14 \pm 0.63^{* *}$ & 41.72 \\
Ethyl acetate extract $(500 \mathrm{mg} / \mathrm{kg})$ & $9.96 \pm 0.29^{* *}$ & 42.76 \\
Chloroform extract $(250 \mathrm{mg} / \mathrm{kg})$ & $11.6 \pm 0.31^{* *}$ & 33.33 \\
Chloroform extract $(500 \mathrm{mg} / \mathrm{kg})$ & $9.15 \pm 0.36^{* *}$ & 47.41 \\
Methanolic extract $(250 \mathrm{mg} / \mathrm{kg})$ & $9.40 \pm 0.51^{* *}$ & 45.98 \\
Methanolic extract $(500 \mathrm{mg} / \mathrm{kg})$ & $7.60 \pm 0.51^{* * *}$ & 56.32 \\
\hline
\end{tabular}

Values are expressed as mean \pm SEM (Standard error mean); ***indicates $\mathrm{P}<0.001$, and **indicates $\mathrm{P}<0.01$; one-way ANOVA followed by Dennett's test as compared to control.

thrombosis is initiated when the activated platelets form platelets to platelets bonds. These activated platelets further bind to the leucocytes and bring them into a complex process of plaque formation and growth [16]. It is the thrombolytic agents that lyse clot by disrupting the fibrinogen and fibrin contained in a clot. Plasmin is one of the natural anti-thrombotic agents. The cell surface bound plasminogen is easily activated to plasmin which ultimately leads to fibrinolysis [17]. After a long process of trial and error the scientists have discovered several thrombolytic drugs from various sources. To make those drugs more site specific and effective some of them have been modified with modern recombinant technology. Streptokinase (a bacterial plasminogen activator), a widely used thrombolytic agent, is capable of converting additional plasminogen to plasmin. But this drug has several adverse effects like bleeding and embolism which lead to further complications. To overcome these complications a number of studies have been conducted by various researchers in order to discover new sources of herbs and natural foods and their supplements having antithrombotic effect with minimal adverse effect [6]. As a part of that research work we also tried to find whether the herbal preparations of L. glutinosa leaves possess clot lysis potentiality or not. When we compared the result of positive control (streptokinase) with that of negative control (water), we found that there was negligible amount of clot disruption when water was added to the clot. This prominent result encouraged us to compare four different test samples in the same manner against the negative control and observe significant thrombolytic activity. It was reported that phytochemicals like saponin, alkaloids and tannin are responsible for thrombolytic activity [18]. As the bark extract of L. glutinosa possesses saponin, alkaloids [19], therefore the possibility of the presence of these phytochemicals in the leaves extract may be the probable reason of demonstrating the thrombolytic activity.

It was observed from the study that in both analgesic activity assay models the plant extract demonstrated analgesic effects. This means that the extract may possess both peripheral and central analgesic effects. The leaves extract of L. glutinosa exhibited significant dose dependent inhibition of acetic acid-induced writhing in mice in comparison to that of the control (saline). Acetic acid induces inflammatory pain by impelling capillary permeability [20], and releasing substances that excite pain nerve endings [21]. The peripheral analgesic effect is generally mediated by the NSAIDs through inhibition of cyclooxygenase and/or lipoxygenase (and other inflammatory mediators) or inhibition of pain responses mediated by noiceptors peripherally [22]. Therefore, it is possible that crude extract of $L$. glutinosa leaves may be showing analgesic

Table 3 Anti-inflammatory activity of hydroalcholic extracts of leaves of $L$. glutinosa

\begin{tabular}{|c|c|c|c|c|}
\hline \multirow[t]{2}{*}{ Treatments } & \multicolumn{4}{|c|}{ Paw volume $(\mathrm{mm})$} \\
\hline & $\mathrm{Oh}$ & $1 \mathrm{~h}$ & $2 \mathrm{~h}$ & $3 \mathrm{~h}$ \\
\hline Control & $0.73 \pm 0.04$ & $1.31 \pm 0.19$ & $1.58 \pm 0.02$ & $1.78 \pm 0.03$ \\
\hline Standard & $0.69 \pm 0.04$ & $0.96 \pm 0.05^{* *}$ & $1.34 \pm 0.05^{* * *}$ & $1.64 \pm 0.05^{* * *}$ \\
\hline n-hexane extract (250 mg/kg) & $0.90 \pm 0.14$ & $1.91 \pm 0.04^{* *}$ & $2.02 \pm 0.04^{* *}$ & $2.19 \pm 0.03^{* * *}$ \\
\hline n-hexane extract (500 mg/kg) & $0.71 \pm 0.05$ & $1.60 \pm 0.02^{* *}$ & $1.98 \pm 0.13^{* *}$ & $2.17 \pm 0.04^{* * *}$ \\
\hline Ethyl acetate extract $(250 \mathrm{mg} / \mathrm{kg})$ & $0.91 \pm 0.11$ & $1.11 \pm 0.05^{* *}$ & $1.51 \pm 0.03^{* * *}$ & $1.32 \pm 0.03^{* *}$ \\
\hline Ethyl acetate extract (500 mg/kg) & $0.88 \pm 0.02$ & $1.41 \pm 0.07^{* *}$ & $1.63 \pm 0.10^{* *}$ & $1.77 \pm 0.02^{* * *}$ \\
\hline Chloroform extract (250 mg/kg) & $0.81 \pm 0.04$ & $1.21 \pm 0.06^{* *}$ & $1.42 \pm 0.02^{* *}$ & $1.59 \pm 0.01^{* * *}$ \\
\hline Chloroform extract (500 mg/kg) & $0.69 \pm 0.08$ & $1.00 \pm 0.03^{* *}$ & $1.40 \pm 0.06^{* *}$ & $1.47 \pm 0.03^{* * *}$ \\
\hline Methanolic extract (250 mg/kg) & $0.77 \pm 0.04$ & $1.01 \pm 0.04^{* *}$ & $1.42 \pm 0.03^{* *}$ & $1.51 \pm 0.04^{* * *}$ \\
\hline Methanolic extract (500 mg/kg) & $0.69 \pm 0.05$ & $1.00 \pm 0.04^{* *}$ & $1.40 \pm 0.03^{* *}$ & $1.47 \pm 0.03^{* * *}$ \\
\hline
\end{tabular}

Values are expressed as mean \pm SEM (Standard error mean); Values are calculated as compared to control using one way-ANOVA followed by Dunnet's Test; **indicates $\mathrm{P}<0.05 ;{ }^{* * * i n d i c a t e s} \mathrm{P}<0.001$ vs. control; $\mathrm{n}=5$. 
Table 4 Effect of the hydroalcholic extracts of $L$. glutinosa on yeast-induced pyrexia in mice

\begin{tabular}{cccccc}
\hline Treatment & Initial & Pyretic & $\mathbf{1 ~ h}$ & $\mathbf{2 ~ h}$ & $\mathbf{3 ~ h}$ \\
\hline Control $(10 \mathrm{ml} / \mathrm{kg})$ & $33.33 \pm 0.44$ & $35.70 \pm 0.46$ & $35.66 \pm 0.44$ & $35.77 \pm 0.56$ & $35.39 \pm 0.66$ \\
Standard $(150 \mathrm{mg} / \mathrm{kg})$ & $33.28 \pm 0.42$ & $35.73 \pm 0.55$ & $34.80 \pm 0.68$ & $34.20 \pm 0.63^{* *}$ & $33.32 \pm 0.67^{* * *}$ \\
n-hexane extract $(500 \mathrm{mg} / \mathrm{kg})$ & $33.80 \pm 0.30$ & $36.17 \pm 0.40$ & $35.90 \pm 0.46$ & $35.77 \pm 0.25^{\mathrm{c}}$ & $35.60 \pm 0.17^{\mathrm{b}}$ \\
Ethyl acetate extract $(500 \mathrm{mg} / \mathrm{kg})$ & $33.69 \pm 0.79$ & $35.57 \pm 0.25$ & $35.27 \pm 0.15$ & $35.00 \pm 0.36^{*}$ & $34.87 \pm 0.32^{\mathrm{c}}$ \\
Chloroform extract $(500 \mathrm{mg} / \mathrm{kg})$ & $33.43 \pm 1.37$ & $35.37 \pm 0.60$ & $35.45 \pm 0.70$ & $35.23 \pm 0.21^{\mathrm{c}}$ & $35.17 \pm 0.32^{\mathrm{b}}$ \\
Methanolic extract $(500 \mathrm{mg} / \mathrm{kg})$ & $33.64 \pm 0.80$ & $36.93 \pm 0.54$ & $36.26 \pm 0.68^{* c}$ & $34.13 \pm 0.54^{* *}$ & $32.78 \pm 0.46^{* * *}$ \\
\hline Values are expressed as mean \pm SEM (Standard error mean); Values are calculated using one-way ANOVA followed by Dennett's test; ${ }^{* * *}$ indicates $\mathrm{P}<0.001$, &
\end{tabular}

effect through these mechanisms although the exact mechanism of action is yet to be discovered. Again in hot plate test the extract also showed prominent antinociceptive effect against the standard drug ketorolac. The hot plate response is a more complex supraspinally organized behavior [23]. The $\mu$ receptor is a type of receptor that is commonly known as the pain relief receptor. It has been proved to be a potent receptor in regulating thermal pain [24]. Moreover, activation of $\mu_{2}$ opioid subtype receptor leads to spinal analgesia [25]. Therefore, by considering the test report, it may be assumed that the antinociceptive activity of L. glutinosa leaves extract is likely to be mediated centrally although the exact mechanism is yet to be discovered. Previous studies on different plant extracts showed analgesic effect in animal models and their effects have been attributed to the presence of alkaloids, glycosides, flavonoids and saponins [26,27]. The phytochemical screening of L. glutinosa extract revealed the presence of most of the above-mentioned phytochemicals [20]. Thus it is possible that the analgesic activity of $L$. glutinosa leaves extract can be due to the presence of these phytochemical constituents.

The present study was also conducted to evaluate the probable anti-inflammatory activity of the methanol extract of L. glutinosa leaves on mice in an acute inflammatory model. The carrageenan-induced mice paw oedema is a suitable test for evaluating anti-inflammatory drugs or natural products [28]. Carrageenan induced paw edema is biphasic event. In the first phase there are incidences like release of histamine, serotonin and kinins whereas the second phase of edema is imposed by release of prostaglandins, protease and lysosome. The second phase is sensitive to most clinically effective anti-inflammatory drugs [29]. The results of present study showed that the role of methanolic extract of L. glutinosa leaves against carrageenan induced acute inflammation was significant. The leaves extract at a dose of 250 and $500 \mathrm{mg} / \mathrm{kg}$ showed significant dose dependent reduction in paw size from $1-4 \mathrm{~h}$ and elicited anti-inflammatory response comparable with standard drug ketorolac. This might be due to the inhibition of the biphasic response induced by the carrageenan. Therefore, it is possible that acute anti-inflammatory effect of L. glutinosa leaves may involve multiple mechanisms like inhibition of either cyclooxygenase and/or lypooxygenase enzyme or inhibition of synthesis, release and action of above inflammatory mediators; but the exact mechanism of action needs to be discovered by further investigation.

It is known that fever is provoked by many exogenous substances in animal models, including bacterial endotoxins and microbe infection. These exogenous pyrogens are responsible for the production of different proinflammatory cytokines which stimulate the release of local prostaglandins (PGs) by entering into the hypothalamic circulation and therefore resetting the hypothalamic thermal set point. Thus to regulate the body temperature it is necessary to have a delicate balance between the production and loss of heat. It is the hypothalamus that regulates the set point and also controls body temperature. The non-steroidal anti-inflammatory drugs inhibit the prostaglandin synthetase within the hypothalamus and thereby demonstrate their antipyretic action [30]. The present study revealed that the methanolic extract of L. glutinosa leaves causes a significant antipyretic effect in yeast provoked elevation of body temperature. Here, the methanolic extract caused almost similar result in lowering of body temperature, in comparison to that of standard drug. It may be predicted that the extract their antipyretic action through inhibition of prostaglandin synthetase within the hypothalamus as like as the NSAIDs. Although, there is no direct evidence of L. glutinosa to interfere with prostaglandin synthesis in hypothalamus but it can be supported by a related study in which Dalbergia odorifera extract was found to inhibit prostaglandin biosynthesis [31]. Thus the present pharmacological evidence provides support for the folklore claim of L. glutinosa leaves as an antipyretic agent.

\section{Conclusions}

In light of the results, it can be revealed that the hydroalcoholic extracts of $L$. glutinosa leaves have remarkable thrombolytic, analgesic, anti-inflammatory and antipyretic activities. Therefore, it may presage further studies to better understand the mechanism of such actions scientifically. 


\section{Methods}

Plant material collection and identification

For the investigation, the leaves of L. glutinosa were collected by the authors from Potia, Chittagong, Bangladesh in July 2012. The plant was identified and authenticated by an expert botanist of Bangladesh National Herbarium (DACB), Mirpur, Dhaka (Accession No. 38277) and a voucher specimen was submitted at the herbarium for future reference.

\section{Extract preparation}

Weighed (630 g of the dried and powdered) sample was soaked in $2200 \mathrm{ml}$ of $99 \%$ methanol in clean, sterilized, and flat-bottomed glass container. Afterwards, it was sealed and maintained for 15 days accompanying occasional stirring and agitation. The complete mixture was then subjected to coarse filtration on a piece of clean, white sterilized cotton material and Whatman ${ }^{\odot}$ filter paper. The extract was obtained by evaporation using rotary evaporator (Bibby RE-200, Sterilin Ltd., UK) at $4 \mathrm{rpm}$ and $65^{\circ} \mathrm{C}$ temperature. It rendered a gummy concentrate of greenish color. The gummy concentrate was designated as crude extract or methanolic extract. Then the crude methanolic extract was dried by freeze drier and preserved at $+4^{\circ} \mathrm{C}$ (yield $0.79 \%$ ). The concentrated methanolic extract was partitioned by modified Kupchan method [32] and the resultant aqueous soluble partitionates i.e., nhexane (yield approx. 19.02\%), ethyl acetate (yield approx. 26.54\%), and chloroform (yield approx. 6.59\%) soluble fractions were used for the experimental processes.

\section{Chemicals}

All the chemicals used in this study were of analytical grade, and purchased from Sigma Chemical Co. (St. Louis, MO, USA), and Merck (Darmstadt, Germany). To the commercially available lyophilized S-Kinase ${ }^{\text {тм }}$ (Streptokinase) vial (Batch no: VEH 09, Popular Pharmaceutical Ltd.,

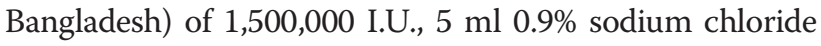
$(\mathrm{NaCl})$ was added and mixed properly. This solution was used as a stock from which $100 \mu \mathrm{l}$ (30,000 I.U) was used for in vitro thrombolysis assay.

\section{Test animals}

For the screening of in vivo antipyretic, analgesic, and anti-inflammatory potential of hydroalcoholic extracts of L. glutinosa leaves, young Swiss-albino mice (aged 20-25 days) of either sex, average weight 20-25 g were used. They were collected from the Animal Resources Branch of ICDDR, B (International Centre for Diarrheal Disease and Research, Bangladesh). After collection, they were kept in favorable condition for one week for adaptation and fed rodent food and water ad libitum formulated by ICDDR,B. Throughout the experiments, all animals received human care according to the criteria outlined in the 'Guide for the Care and Use of Laboratory Animals', 8th edition, prepared by the National Academy of Sciences and published by the National Institute of Health (US).

\section{Thrombolytic assay}

In vitro clot lysis activity of the leaves was carried out according to the method of Prasad et al. [33] with minor modifications. With ethical considerations, and aseptic precaution, $7 \mathrm{ml}$ of venous blood was drawn from healthy volunteers $(n=5)$ having no history of smoking, taking lipid lowering drugs, oral contraceptive or anticoagulant therapy and transferred to different pre weighed sterile micro-centrifuge tube (1 $\mathrm{ml} /$ tube). The microcentrifuged tubes were subjected to incubation at $37^{\circ} \mathrm{C}$ for $45 \mathrm{~min}$. After the formation of clot, serum was completely removed from the tubes (carried out without disturbing the clot formed) and each tube having clot was again weighed to determine the weight of the clot (clot weight = weight of clot containing tube - weight of tube alone).

To each micro-centrifuge tube containing pre-weighed clot, $100 \mu$ l solution of different extracts (n-hexane, ethyl acetate, chloroform and methanolic extract), concentration $1 \mathrm{mg} / \mathrm{mL}$, were added accordingly. As a positive control, $100 \mu \mathrm{l}$ of streptokinase and as a negative non thrombolytic control, $100 \mu \mathrm{l}$ of sterilized distilled water were separately added to the control tubes numbered. Then all the tubes were incubated again at $37^{\circ} \mathrm{C}$ for $90 \mathrm{~min}$ and observed for clot lysis. After incubation, the obtained fluid was removed from the tubes and they were again weighed to observe the difference in weight after clot disruption. At last, difference obtained in weight was calculated and the result was expressed as percentage of clot lysis following the underneath equation.

$\%$ of clot lysis $=($ wt. of released clot $/$ clot wt. $) \times 100$

\section{Analgesic activity test}

In the current investigation two different methods were employed for testing the possible peripheral and central analgesic effects of L. glutinosa leaves; namely acetic acid induced writhing test and hot plate test in mice respectively.

\section{Hot plate test}

The hot plate test was performed following the method of Asongalem et al. [34]. Pain reflex in response to the thermal stimulus was measured using a Le7406 hot plate (Panlab S2, Cornella, Barcelona, Spain). Before $30 \mathrm{~min}$ of the test, mice were placed in ten different groups comprising six (6) mice in each group and were intragastrically treated in the following manner: group I was treated with negative control (isotonic saline solution, $0.9 \%$ ), group II with positive control (ketorolac) as reference drug (10 $\mathrm{mg} / \mathrm{kg}$ body weight), and groups III-X 
with the plant extracts at dose of 250 and $500 \mathrm{mg} / \mathrm{kg}$ body weight. Mice were placed on a $55 \pm 1^{\circ} \mathrm{C}$ hot plate in order to obtain their response to electrical heat-induced nociceptive pain stimulus judged by the presence of behaviors such as licking of the fore and hind paws or jumping. The pain response was measured at $30 \mathrm{~min}$ and at every hour thereafter for $4 \mathrm{~h}$. The cut-off time used to prevent skin damage was $25 \mathrm{sec}$.

\section{Acetic acid induced writhing test}

The analgesic activity of the crude methanolic extract was studied using acetic acid induced writhing model in mice $[10,35]$. The animals were divided into four groups including control (Group I), positive control (Group II) and two test groups (Group III-IV). The animals of group III and IV were administered test substance at the dose of 250 and $500 \mathrm{mg} / \mathrm{kg}$ body weight respectively. Positive control group received ketorolac (standard drug) at the dose of $10 \mathrm{mg} / \mathrm{kg}$ body weight and vehicle control group was treated with $1 \%$ Tween 80 in distilled water at the dose of $10 \mathrm{ml} / \mathrm{kg}$ body weight. Test samples, standard drugs and control vehicle were administered orally $30 \mathrm{~min}$ before intraperitoneal administration of $0.7 \%$ acetic acid. After 15 min of time interval, the writhing (constriction of abdomen, turning of trunk and extension of hind legs) was observed on mice for $5 \mathrm{~min}$.

\section{Anti-inflammatory activity test}

Carrageenan induced mice hind paw edema was used as the animal model of acute inflammation according to the method of Lanhers et al. [36]. In this experiment, the mice were divided into four groups of five animals each. Group I (control) received 2\% Tween 80 in normal saline $(2 \mathrm{ml} / \mathrm{kg})$. Group II (Positive control) received $10 \mathrm{mg} / \mathrm{kg}$ body wt. of ketorolac orally. Group III and IV received 250 and $500 \mathrm{mg} / \mathrm{kg}$ body wt. of the extract orally respectively. Acute inflammation was induced in all the four groups by sub plantar injection of $0.05 \mathrm{ml}$ of its suspension of Carrageenan with $2 \%$ Tween 80 in normal saline in the right Paw of the mice 30 minutes after the oral administration of the tested materials. The paw volume was measured with a micrometer screw gauze at 1,2 , 3 and $4 \mathrm{~h}$ after the administration of the drug and the extract. The percentage inhibition of inflammatory effect of the extract was calculated using the following expression:

Percentage inhibition of inflammation $=[(\mathrm{Vc}-\mathrm{Vt}) / \mathrm{Vc}] \times 100$

Where Vc is the average degree of inflammation by the control group and $\mathrm{Vt}$ is the average degree of inflammation by the test group.

\section{Antipyretic activity test}

The antipyretic activity was evaluated by Brewer's yeast induced pyrexia in experimental animal [37]. Hyperpyrexia was induced by subcutaneous administration of $10 \mathrm{ml} / \mathrm{kg}$ body weight $20 \%$ aqueous suspension of brewer's yeast. The selected animals were fasted overnight with water $a d$ libitum before the experiments. Initial rectal temperature of animals was recorded using an Ellab thermometer $\left(33.19 \pm 0.40^{\circ} \mathrm{C}\right)$. After $18 \mathrm{~h}$ of subcutaneous administration, the animals that showed an increase of $0.3-0.5^{\circ} \mathrm{C}$ in rectal temperature were selected for the antipyretic activity. Crude methanolic extract of plant was given orally (500 mg/kg). Paracetamol (150 mg/kg orally) was used as reference drug, whereas, control group received distilled water $(10 \mathrm{ml} / \mathrm{kg})$ only. The rectal temperature was recorded at $1 \mathrm{~h}$ intervals for $3 \mathrm{~h}$ after treatment [38].

\section{Statistical analysis}

One way ANOVA with Dunnett's post Hoc test for this experiment was carried out with SPSS 16.0 for Windows $^{\oplus}$ software and the results obtained were compared with the control group. P values $<0.001$ were considered to be statistically significant.

\section{Competing interests \\ The authors declare that they have no competing interests.}

\section{Authors' contributions}

$\mathrm{RB}$ and $\mathrm{BD}$ carried out the collection of plants extraction process and conducting the experiments. MSI* and MSS carried out conception and design of the study, analysis and interpretation of data. SMRD and AD wrote the manuscript, and done the statistical analysis. MMNU and MSI revised the manuscript. All authors read and approved the final manuscript.

\section{Acknowledgments}

The authors are grateful to DACB for identifying the plant and also thankful to Department of Pharmacy, Noakhali Science and Technology University for providing the laboratory facilities.

\section{Author details}

${ }^{1}$ Department of Pharmacy, Noakhali Science and Technology University, Sonapur, Noakhali 3814, Bangladesh. ${ }^{2}$ Department of Pharmacy, Southeast University, Dhaka 1213, Bangladesh. ${ }^{3}$ Department of Oncology, Ashic Oncology and Palliative Care Center, Dhaka 1207, Bangladesh. ${ }^{4}$ Department of Pharmacy, University of Chittagong, Chittagong 4331, Bangladesh. ${ }^{5}$ Department of Pharmacy, Manarat International University, Dhaka 1216, Bangladesh.

Received: 10 June 2014 Accepted: 13 October 2014

Published: 29 October 2014

\section{References}

1. Ellof JN: Which extractant should be used for the screening and isolation of antimicrobial components from plants? J Ethnopharmacol 1998, 60:1-6.

2. Ghani A: Medicinal plants of Bangladesh: Chemical constituents and uses. Nimtali, Dhaka: Asiatic Society of Bangladesh; 2003:285.

3. Chowdhury JU, Bhuiyan MNI, Nandi NC: Aromatic plants of Bangladesh: essential oils of leaves and fruits of Litsea glutinosa (Lour.) C.B. Robinson. Bangladesh J Bot 2008, 37:81-83.

4. Haque T, Uddin MZ, Saha ML, Mazid MA, Hassan MA: Propagation, antibacterial activity and phytochemical profiles of Litsea glutinosa (Lour.) C.B. Robinson. Dhaka Univ J Biol Sci 2014, 23:165-171.

5. Chatterjee A, Pakrashi S: The Treatise of Indian Medicinal Plants. New Delhi, India: INSA; 1994:107. 
6. Dewan SMR, Das A: Investigation of in vitro thrombolytic potential and phytochemical nature of Crinum latifolium L. leaves growing in coastal region of Bangladesh. Int J Bio Pharm Res 2013, 4:1-7.

7. Prasad S, Kashyap RS, Deopujari JY, Purohit HJ, Taori GM, Daginawala HF: Development of an in vitro model to study clot lysis activity of thrombolytic drugs. Thromb J 2006, 4:14.

8. Khan IN, Habib MR, Rahman MM, Mannan A, Sarker MM, Hawlader S: Thrombolytic potential of ocimum sanctum L., curcuma longa $L$., azadirachta indica L. and anacardium occidentale L. J Basic Clin Pharm 2011, 2:125-127.

9. Loeser JD, Treede RD: The Kyoto protocol of IASP basic pain terminology. Pain 2008, 137:473-477.

10. Dewan SMR, Amin MN, Adnan T, Uddin SMN, Shahid-Ud-Daula AFM, Sarwar G, Hossain MS: Investigation of analgesic potential and in vitro antioxidant activity of two plants of Asteraceae family growing in Bangladesh. J Pharm Res 2013, 6:599-603.

11. Hossain H, Shahid-Ud-Daula AFM, Hasan K, Mansur AA, Haq MM: Anti-inflammatory activity, total flavonoids and tannins content from the ethanolic extract of Spilanthes paniculata leaf growing in Bangladesh. Int J Pharm 2012, 2:271-277.

12. Halliwell B, Gutteridge JMC, Cross CE: Free radicals, antioxidants, and human disease: where are we now? J Lab Clin Med 1992, 119:598-620.

13. Spacer CB, Breder CD: The neurologic basics of fever. N Engl J Med 1994, 330:1880-1886.

14. Luo C, BOHLIN L: Is COX-2 a perpetrator or a protector? Selective COX-2 inhibitors remain controversial1. Acta Pharmacologica Sinica 2005, 26:926-933.

15. Furie B, Furie BC: Mechanisms of thrombus formation. N Engl J Med 2008 , 359:938-949.

16. Das A, Dewan SMR, Ali MR, Debnath PC, Billah MM: Investigation of in vitro thrombolytic potential of ethanolic extract of Momordica charantia fruits: An anti-diabetic medicinal plant. Der Pharmacia Sinica 2013, 4:104-108.

17. Pantzar M, Ljungh A, Wadström T: Plasminogen binding and activation at the surface of Helicobacter pylori CCUG 17874. Infect Immun 1998, 66:4976-4980.

18. Chowdhury NS, Alam MB, Haque ASMT, Zahan R, Mazumder MEH, Haque ME: In vitro free radical scavenging and thrombolytic activities of Bangladeshi aquatic plant Aponogeton undulatus Roxb. Global $J$ Pharmacol 2011, 5:27-32.

19. Parikh PH, Rangrez AY: Extraction and phytochemical evaluation of Litsea Glutinosa bark methanolic extract. J App Pharm Sci 2012, 2:71-78.

20. Amico-Roxas M, Caruso A, Trombadore S, Scifo R, Scapagnini U: Gangliosides antinociceptive effects in rodents. Arch Int Pharmacodyn Ther 1984, 272:103-117.

21. Raj PP: Pain medicine: a comprehensive review. 1st edition. Missouri: Mosby - year book; 1996.

22. Koster R, Anderson M, De Beer EJ: Acetic acid for analgesic screening. Fed Proc 1959, 18:418-420

23. Chapman $\mathrm{CR}$, Casey KL, Dubner R, Foley KM, Gracely RH, Reading AE: Pain measurement: an overview. Pain 1985, 22:1-31.

24. Dhawan BN, Cesselin F, Raghubir R, Reisine T, Bradley PB, Protoghese PS, Haman M: Classification of opioid receptors. Pharmacol Rev 1996, 48:567-592.

25. Lipman AG, Jackson RC: Principles and Practice of Pain Medicine. 2nd edition. New York: McGraw-Hill; 2004:585-588.

26. Perazzo FF, Souza GH, Lopes W, Cardoso LG, Carvalho JC, Nanayakkara NP, Bastos JK: Anti-inflammatory and analgesic properties of water-ethanolic extract from Pothomorphe umbellate (Piperaceae) aerial parts. J Ethnopharmacol 2005, 99:215-220.

27. Ramaswamy S, Pillai NP, Gopalakrishnan V, Parmar NS, Ghosh MN: Analgesic effect of O-(beta-hydroxy ethyl) rutoside in mice. Indian J Exp Biol 1985, 23:219-220.

28. Banerjee S, Sur TP, Mandal S, Das PC, Sikdar S: Assessment of the antiinflammatory effects of Swertia chirata in acute and chronic experimental models in male albino rats. Indian J Pharmacol 2000, 32:21-24.

29. Vinegar R, Schreiber W, Hugo R: Biphasic development of carrageenan edema in rats. J Pharmacol Exp Therapeut 1969, 166:96-103.

30. Hayare SW, Chandra S, Tandan SK, Sarma J, Lal J, Telang AG: Analgesic and antipyretic activities of Dalbergia sissoo leaves. Indian J Pharmacol 2000, 32:357-360

31. Goda Y, Kiuchi F, Shibuya M, Sankawa U: Inhibitors of prostaglandin biosynthesis from Dalbergia odorifera. Chemphart bull 1992, 40:2452-2457.
32. Van Wagenen BC, Larsen $\mathrm{R}$, Cardellina JH, Ran Dazzo D, Lidert ZC, Swithenbank C: Ulosantoin, a potent insecticide from the sponge Ulosaruetzleri. J Org Chem 1993, 58:335-337.

33. Prasad S, Kashyap RS, Deopujari JY, Purohit HJ, Taori GM, Daginawala HF: Effect of Fagonia arabica (Dhamasa) on in vitro thrombolysis. BMC Complement Altern Med 2007, 7:36.

34. Asongalem EA, Foyet HS, Ekobo S, Dimo T, Kamtchouing P: Antiinflammatory, lack of central analgesia and antipyretic properties of Acanthus montanus (Ness) T. Anderson. J Ethnopharmacol 2004, 95:63-68.

35. Whittle BA: The use of changes in capillary permeability in mice to distinguish between narcotic and nonnarcotic analgesics. $\mathrm{Br} J$ Pharmacol Chemother 1964, 22:246-249.

36. Lanhers MC, Fleurentin J, Dorfman P, Motrier F, Pelt JM: Analgesic antipyretic and anti- inflammatory properteis of Euphorbia hirta. Planta Medica 1991, 57:225-231.

37. Loux JJ, Deplama PD, Yankel SL: Antipyretic testing of aspirin in rats. Toxicol Appl Pharmacol 1972, 22:672-675.

38. Abena AA, Diatewa M, Gakosso G, Gbeassor M, Hondi-Assah T, Ouamba JM: Analgesic, antipyretic and anti-inflammatory effects of essential oil of Lippia multiflora. Fitoterapia 2003, 74:231-236.

\section{doi:10.1186/0717-6287-47-56}

Cite this article as: Bhowmick et al.: In vivo analgesic, antipyretic, and anti-inflammatory potential in Swiss albino mice and in vitro thrombolytic activity of hydroalcoholic extract from Litsea glutinosa leaves. Biological Research 2014 47:56

\section{Submit your next manuscript to BioMed Central and take full advantage of:}

- Convenient online submission

- Thorough peer review

- No space constraints or color figure charges

- Immediate publication on acceptance

- Inclusion in PubMed, CAS, Scopus and Google Scholar

- Research which is freely available for redistribution 